Clinical science

\title{
INFLUENCE OF ALENDRONATE THERAPY ON THE RESULTS OF DENSITOMETRIC EXAMINATION AFTER IMPLANTATION OF TOTAL HIP ENDOPROSTHESIS
}

Ilir Shabani ${ }^{1}$, Antonio Gavrilovski ${ }^{1}$, Vilijam Velkovski ${ }^{1}$, Nenad Atanasov ${ }^{1}$, Shaban Memeti², Anila Belchishta ${ }^{1}$

University Clinic for Traumatology, Orthopedics, Anesthesiology, Reanimation and Intensive Care; Ss Cyril and Methodius in Skopje, Faculty of Medicine, Republic of North Macedonia

University Clinic for children's susrgery; Ss. Cyril and Methodius University in Skopje, Faculty of Medicine, Republic of North Macedonia

Citation: Shabani I, Gavrilovski A, Velkovski V Atanasov N, Memeti S, Belchishta A. Influence of alendronate therapy on the results of densitometric examination after implantation of total hip endoprosthesis. Arch Pub Health 2021; 13 (1).

doi.org/10.3889/aph.2021.5994

Key words: otal hip endoprosthesis, alendronate therapy, DXA

*Correspondence: Ilir Shabani. University Clinic for Traumatology, Orthopedics, Anesthesiology, Reanimation and Intensive Care, Skopje, Republic of North Macedonia. E-mail: dr_ilir_shabani@yahoo.com

Received: 23-Feb-2021; Revised: 20-Apr-2021; Accepted: 25-Apr-2021; Published: 30-Apr-2021 Copyright: ${ }^{\circledR 2021}$. Ilir Shabani, Antonio Gavrilovski, Vilijam Velkovski, Nenad Atanasov, Shaban Memeti, Anila Belchishta. This is an open-access article distributed under the terms of the Creative Common Attribution License, which permits unrestricted Attribution License, which permits unrestricte use, distribution, and reproduction in any medium, provided the original author(s) and source are
credited.

Competing Interests: The author have declared that no competing interests

\begin{abstract}
The development of aloarthroplasty of the hip is continuously rising. After implantation of a total cement-free hip endoprosthesis, often there is a periprosthetic femoral bone loss. Alendronate has been shown to be a potent inhibitor of bone resorption activity; it inhibits osteoclastic bone resorption, increases bone mass, and plays a significant role in post-implantation stabilization of the femur. The aim of this study was to determine the effect of alendronate on osteointegration of hip endoprosthesis.Material and methods: The study analyzed 10 patients operated on with implantation of a total cement-free hip endoprosthesis (THP). The included patients were examined by a radiographic method at 6 and 12 months and DXA method at 6 and 12 months. Results: The study showed differences in the values of bone mineral density and bone mineral content in the interval between 6 and 12 months in patients undergoing THP, and hence we can conclude that alendronate therapy after THP implantation reduced periprosthetic loss of bone mass and implant stiffening. Alendronate is a proven inhibitor of periprosthetic bone loss that occurs after prirmary impantation of a total cement-free hip endoprosthesis
\end{abstract}

\section{ВЛИЈАНИЕ НА АЛЕНДРОНАТНАТА ТЕРАПИЈА ВРЗ РЕЗУЛТАТИТЕ ОД ДЕНЗИТОМЕТРИСКОТО ИСПИТУВАҢЕ ПО ИМПЛАНТАЦИЈА НА ТОТАЛНА ЕНДОПРОТЕЗА НА КОЛКОТ}

Илир Шабаниㄹ, Антонио Гавриловскиㄹ, Вилијам Велковскиㄹ, Ненад Атанасовㄹ, Шабан Мемети², Анила Белчишта ${ }^{1}$

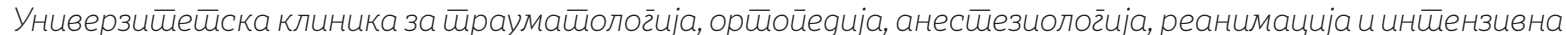
нег̄a; Универзийей Св Кирил и Мейоgиј во Скойје, Меgицински факулйей, Рейублика Северна Макеgонија

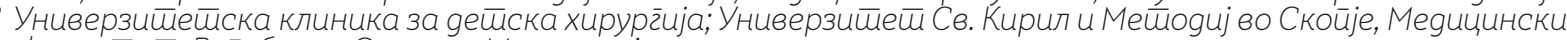
факулиеиеи, Рейублика Северна Макеgонија

Цитирање: Шабани И, Гавриловски А, Велковски В, Атанасов Н, Мемети Ш, Белчишта А. Влијание на алендронатната терапија врз резултатите од дензитометриското испитување резултатите од дензитометриското испитување по имплантација на тотална ендопротеза на колкот. Арх Ј Здравје 2021;13(1)

doi.org/10.3889/aph.2021.5994

Клучни зборови: тотална ендопротеза на колк, алендронатна терапија, DXA

*Кореспонденција: Илир Шабани, Универзитетска клиника за трауматологија, ортопедија, гетска клиника за трауматологија, ортопедија, нега, Скопје, Република Северна Македонија. E-mail: dr_ilir_shabani@yahoo.com

П-mail: dr_llir_shabani@yahoo.com Прифатено: 25-апр-2021 Објавено: 30-апр-2021

Печатарски права: ${ }^{\circledR 2021 ~ И л и р ~ Ш а б а н и, ~ А н т о-~}$ нио Гавриловски, Вилијам Велковски, Ненад Атанасов, Шабан Мемети, Анила Белчишта. Оваа статија е со отворен пристап дистрибу ирана под условите на нелокализирана лицен ца, која овозможува неограничена употреба, дистрибуција и репродукција на било кој медиум, доколку се цитираат оригиналниот(ите) автор(и) и изворот.

Конкурентски интереси: Авторот изјавува дека нема конкурентски интереси.

\section{Извадок}

Развојот на алоартропластиката на колкот во денешно време е во подем. Честопати по вградување на тотална безцементна ендопротеза на колкот доаѓ до перипростетична коскена загуба во фемурот. Алендронатот е докажан потентен инхибитор на коскената ресорптивна активност, ја инхибира остеокластната коскена ресорпција, а ја зголемува коскената маса и има значајна улога во постимплантационата стабилизација на фемурот. Целта на трудот е да се процени вредноста на примена на алендронатот во намалување на редукција на перипростетична остеолиза после имплантација на тотална безцементна ендопротеза на колкот. Материјал и методи: Во студијата беа анализирани 10 пациенти оперирани со имплантација на тотална бесцементна ендопротеза на колк (ТПК). Испитуваните пациенти постоперативно примаа орално алендронат, калциум и витамин Д3. Пациентите беа иследувани со радиографскиот метод на 6 и 12 месеци и DXA методот исто така на 6 и 12 месеци. Резултати: Студијата покажа разлики во вредностите на коскената минерална густина и коскената минерална содржина во интервалот меѓу 6 и 12 месеци кај пациенти оперирани со ТПК, од која заклучуваме дека алендронатната терапија после вградување на ТПК овозможува намалување на перипростетичната загуба на коскената маса и зацврстување на имплантот. Алендронатот е докажан инхибитор на перипростетичната коскена загуба, која се јавува после примарната имплантација на тоталната бесцементна ендопротеза на колкот. 


\section{Introduction}

Implantation of cement-free endoprosthesis, as a method for functional reconstruction of the hip, ensures bone growth in irregular surfaces and achieves its stable biological fixation. ${ }^{1,2}$

The implantation of cement-free implants depends on several basic factors:

- the design of the applied implant,

- the biological capacity of the entire anatomical segment where the implant is implanted

- the biological potential of the organism as a whole. . $^{3,45}$

Good primary fixation of both components (acetabular and femoral), elimination of all irritating components (physical, chemical, mechanical and biological) are prerequisites defined under the terms biostability and biocompatibility.

Following the experience in implantation of total hip prosthesis, the most common complication that occurs is aseptic loosening of the prosthesis components whose incidence increases over the postoperative time, forcing prosthesis reoperation.

One of the possibilities for postimplantation reduction of periprosthetic bone loss is the use of modern drug bisphosphonate therapy with alendronate. ${ }^{6-8}$

Alendronate (alendronic acid - alendronate sodium) is a bisphosphonate drug that is a potent inhibitor of bone resorption activity. It inhibits osteoclastic bone resorption. Like other bisphosphonates, it is chemically linked to inorganic pyrophosphates and is an endogenous regulator of the bone metabolism. At the cellu- lar level, it enables reduction of bone metabolism, increases bone mass and confirms mineralization of the bone matrix. ${ }^{9-12}$

Bisphosphonate therapy with alendronate at a therapeutic dose of $10 \mathrm{mg}$ daily $+1000 \mathrm{mg}$ calcium and vitamin D3 for 18 months provides opportunities for prevention of periprosthetic osteolysis, which is expected to make a significant progress in post-implant stabilization of implanted endoprosthetic implants and a risk of their premature loosening accompanied by all its consequences. ${ }^{13-15}$

The first published experiences for the use of bisphosphonate therapy with alendronate in the direction of reduction of periprosthetic osteolysis showed that it resulted in a significant reduction in periprosthetic bone loss after primary THP implantation compared to the group of patients who did not undergo the above therapy. ${ }^{16-19}$

In 2003 Nehme A. et al. examined the effect of alendronate on the reduction of periprosthetic bone loss over a period of two years. During that period, in the control group, the bone loss reached a plateau 6 months after the implantation of the total hip prosthesis measured by the DXA method and it reached $12.7 \%$ of bone loss at the end of the second year. In the alendronate group, there was no plateau; bone density continued to increase, and bone loss reached a maximum of $6.85 \%$ by the end of the second year. ${ }^{20}$

In 2005, Tcing Hua et al. reduced periprosthetic osteolysis induced by residual implant particles in patients undergoing alendronate therapy. According to these authors, the mechanism of reduction of periprosthetic osteolysis consisted in an increase in 
osteoprotegerin, a protein produced by a direct secretion from osteoblasts. ${ }^{21-23}$

In 2006, Li Hong-bin performing experimental analyses of animal models came to the realization of a significant increase in periprosthetic bone growth after oral administration of alendronate. ${ }^{24-26}$

In all the above test results, periprosthetic bone reduction mainly occured in the first 6 months after implantation of a total cement-free hip prosthesis. In this regard, DXA studies have shown that patients with low preoperative values for bone mineral density tend to have the greatest bone loss after implantation of a total hip endoprosthesis. ${ }^{27-29}$

The aim of this study was to evaluate the value of alendronate application in reducing the periprosthetic osteolysis after implantation of a total cement-free hip endoprosthesis.

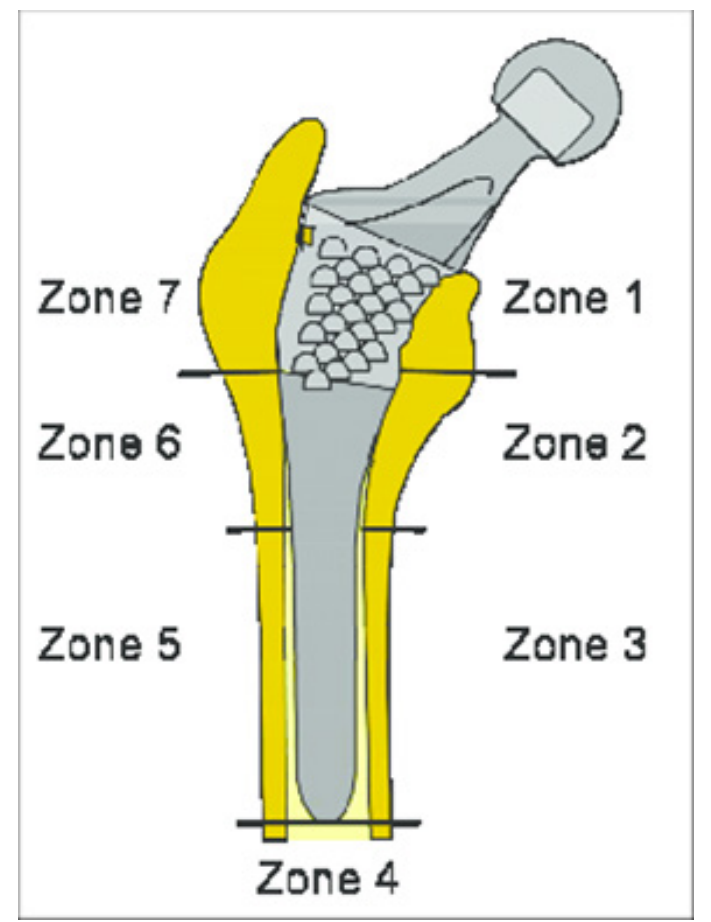

Figure 1

Schematic representation of Gruen zones

\section{Material and method}

The clinical material included 10 patients treated at the University Clinic for Orthopedic Diseases with implantation of a total hip endoprosthesis in the period from 2016 to 2018 due to degenerative diseases of the hip.

All patients in the study were clinically and osteodensitometrically without visible signs of osteoporosis. All patients underwent spinal anesthesia with anterolateral hip approach, with standard verticalization 3 days after the operative treatment and a standard postoperative rehabilitation period. All were permanently treated with alendronate bisphosphonate therapy as well as standard vitamin therapy and calcium substitution therapy per os.

This study was based on a clinical trial using two diagnostic methods: native hip radiography and dual energy X-ray absorption (DXA). Densi-

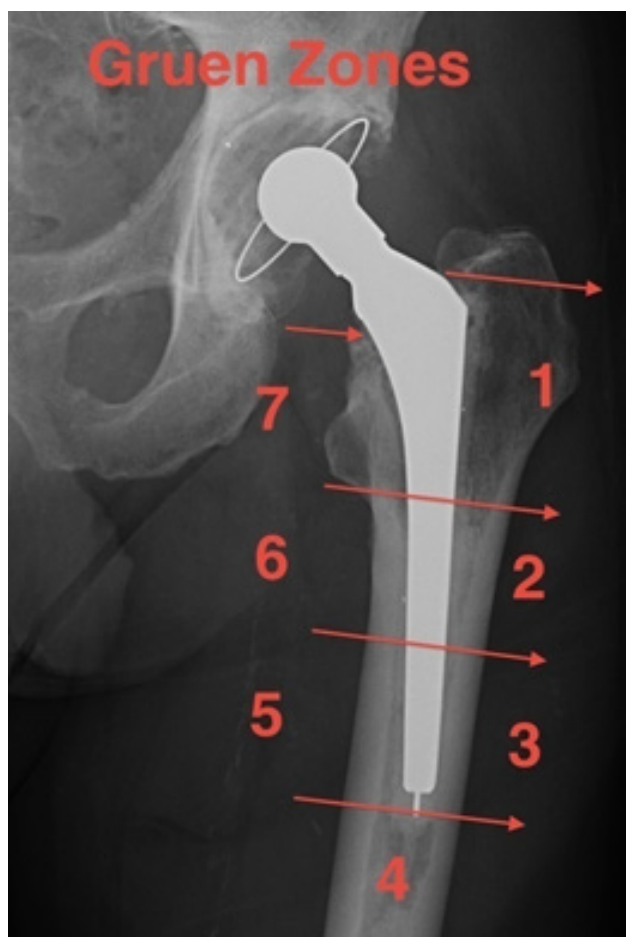

Figure 2

Native X-ray with marked Gruen zones 
tometric analysis refers to 7 Gruen zones of the femur, through which periprosthetic osteolysis is formed in the femur, after implantation of total hip prosthesis (THP) is assessed (Fig. 1 and 2). The results of both examinations were obtained and analyzed at 6 and 12 months after the surgical intervention.

The analysis consisted of comparing the results for BMD (bone mineral density) and BMC (bone mineral content) obtained at different time points.

In this initial phase of the study, ten patients were available and were treated with alendronate therapy. Bone mineral concentration (BMC) and bone mineral density (BMD) were determined in all of them at two time points: 6 months and 12 months from the beginning of alendronate therapy.

In each patient, BMC and BMD measurements were performed at the level of the seven Gruen zones-points $(1,2,3,4,5,6$, and 7) (see Figure 1 and
Figure 2).

In each patient, we calculated the arithmetic means (averages) of the measured values of BMC and BMD in the seven points, especially after 6 months, and after 12 months.

\section{Results}

The age distribution of patients was 45-65 years, of which 7 were females and 3 males. These arithmetic means (averages) for all 10 patients are shown in Table 1. Furthermore Figure 3 shows the graphical comparison of the obtained values. It is evident that in all patients the BMC and BMD values were higher after 12 months of alendronate therapy, compared to the values after only 6 months. This supports the effectiveness of alendronate therapy in reducing bone loss after implantation of a total hip endoprosthesis.

Table 1. BMC and BMD after 6, that is, 12 months after administration of alendronate therapy and structure by gender and age in 10 patients with total cement-free hip endoprosthesis

\begin{tabular}{|c|c|c|c|c|c|c|}
\hline Nr. & Gender & Age & BMC_6 & BMC_12 & BMD_6 & BMD_12 \\
\hline 1 & F & 64 & 5.940 & 4.550 & 1.251 & 1.513 \\
\hline 2 & M & 57 & 9.610 & 8.790 & 1.573 & 1.914 \\
\hline 3 & F & 62 & 7.791 & 8.876 & 1.300 & 1.500 \\
\hline 4 & M & 48 & 4.334 & 4.681 & .987 & 1.220 \\
\hline 5 & F & 53 & 5.054 & 5.763 & 1.075 & 1.446 \\
\hline 6 & F & 52 & 5.326 & 8.695 & 1.085 & 1.520 \\
\hline 7 & F & 48 & 5.031 & 5.356 & 1.069 & 1.324 \\
\hline 8 & F & 52 & 8.876 & 9.276 & 1.500 & 1.928 \\
\hline 9 & F & 61 & 7.821 & 8.751 & .928 & 1.090 \\
\hline 10 & M & 60 & 8.996 & 9.286 & 1.421 & 1.692 \\
\hline
\end{tabular}


Figure 1. BMC and BMD values 6 and 12 months after administration of alendronate therapyendoprosthesis

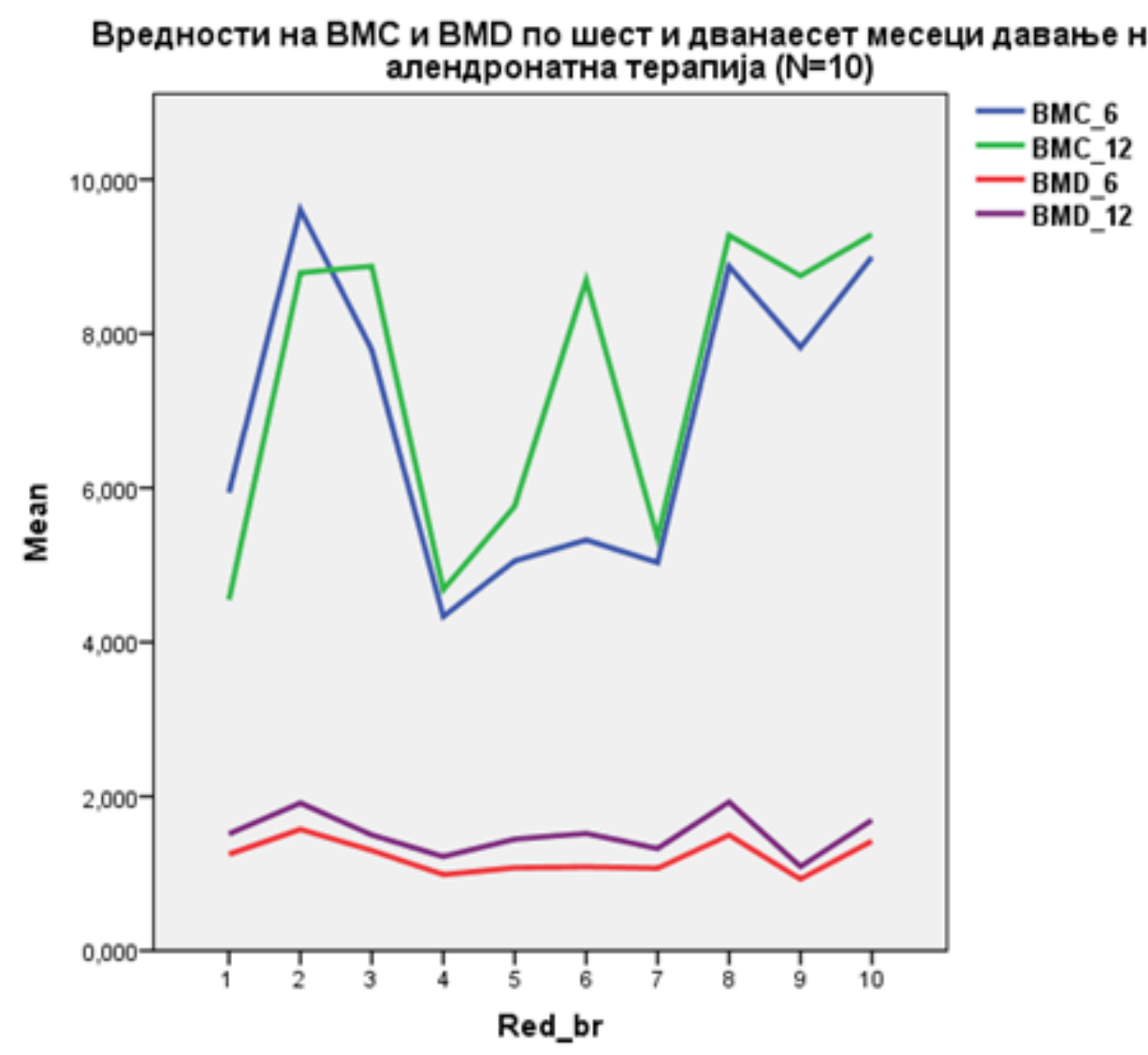

\section{Discussion}

In our study, BMC and BMD values were found to be higher after 12 months of alendronate therapy compared to values after only 6 months. Studies investigating periprosthetic BMD have shown that the most significant bone loss occurs in the first 3 to 6 months after endoprosthesis implantation, followed by a period of stabilization during the first postoperative year. ${ }^{9-27}$

Few studies have investigated the effect of alendronate on periprosthetic bone loss. A prospective randomized study examined 13 patients treated for coxarthrosis with a cement-free hip endoprosthesis. Patients were randomized to receive only calcium or calcium alendronate. This study showed that in patients treated with alendronate bone loss was significantly lower than in the control group $(0,9 \%$ vs. $17.1 \%$ for proximal Gruen zones and $2.6 \%$ vs. 9.9\% for all Gruen zones). ${ }^{28}$

In our group of patients, the results have shown an increase in BMD in all Gruen zones for all patients individually over a period of 6 months (measured 6 and 12 months after surgery), indicating the benefit of alendronate in reducing periprosthetic osteolysis.

Our results regarding the values of BMD, but also BMC, support the potential benefit of alendronate in improving denture implantation, as studies show that the mechanism of action of alendronate is expressed through an increase in bone mass of the cortical and trabecular bones, with the largest increase being in the trabecular bone, 
which is necessary for implantation of the cement-free stem. ${ }^{29}$

\section{Conclusion}

Alendronate is a proven inhibitor of periprosthetic bone loss that occurs after primary implantation of a total cement-free hip endoprosthesis. Our preliminary study reaffirms the effect of bisphosphonate therapy as an inhibitor of periprosthetic bone loss and aseptic implant loosening.

\section{References:}

1. Kobayashi S, Saito N, Horiuchi H, Iorio R, Takaoka K. Poor bone quality or hip structure as a risk factors affecting survival of total hip arthroplasty. Lancet 2000;355:1499-1504.

2. Taylor M, Tanner KE. Fatigue failure of cancellous bone: a possible cause of implant migration and loosening. J Bone Joint Surg Br 1997;779:181-182.

3. Bobyn JD, Mortimer ES, Glassman $\mathrm{AH}$, et al. Producing and avoiding stress shielding. Laboratory and Clinical observation of noncemented total hip arthroplasty. Clin Orthop Relat Res 1992;274:79-96.

4. Huiskes R. The various stress patterns of press-fit, ingrown, and cemented femoral stems. Clin Orthop Relat Res 1990;(261):27-38.

5. Sychterz CJ, Engha CA. The influence of clinical factors on periprosthetic bone remodeling Clin Orthop Relat Res 1995;322:285-292.

6. Kiratli BJ, Checovich MM. Mc Beath AA, Wilson MA, Heiner JP. Measurment of bone mineral density by DEXA in patiens with a Wisconsin hip, an uncemented femoral stem. J Arthroplasty 1996;1(2):184-193
7. Hosking D, Chilvers CE, Christiansen $C$ et al. Prevention of bone loss with alendronate in postmenopausal women under 60 years of age. Early Postmenopausal Intervention Cohort Study Group. N Engl J Med 1998;338(8):485-492) 1(2):184-193

8. McCarthy CK, Steinberg GG, Agren M, Leahey D, Wyman E, Baran DT. Quantifying bone loss from the proximal femur after total hip arthroplasty. J Bone Joint Surg $\mathrm{Br}$ 1991; 73(5):774-778.

9. Kiratli BJ, Checovich MM, McBeath AA, Wilson MA, Heiner JP. Measurement of bone mineral density by dual-energy $\mathrm{x}$-ray absorptiometry in patients with the Wisconsin hip, an uncemented femoral stem. J Arthroplasty 1996; 11(2):184-193.

10. Kröger H, Venesmaa P, Jurvelin J, Miettinen $\mathrm{H}$, Suomalainen O, Alhava E. Bone density at the proximal femur after total hop arthroplasty. Clin Orthop Relat Res 1998; (352):66-74.

11. Brodner W, Bitzan P, Lomoschitz $F$, et al. Changes in bone mineral density in the proximal femur after cementless total hip arthroplasty. A five-year longitudinal study. J Bone Joint Surg Br 2004; 86(1):20-26.

12. Braun A, Papp J, Reiter A. The periprosthetic bone remodeling process-signs of vital bone reaction. Int Orthop 2003; 27(Suppl 1):S7-10.

13. Kobayashi S, Saito N, Horiuchi H, Iorio R, Takaoka K. Poor bone quality or hip structure as risk factors affecting survival of total-hip arthroplasty. Lancet 2000; 355(9214):1499-1504.

14. Woolf AD, Akesson K. Preventing fractures in elderly people. BMJ 2003; 327(7406):89-95.

15. Shanbhag AS. Use of bisphospho- 
nates to improve the durability of total joint replacements. J Am Acad Orthop Surg 2006; 14(4):215-225.

16. Charnley J.Low Friction Arthroplasty of the hip theory and practice. New York ,NY:Spingr Verlog;1979

17. Older J.Charnley low-friction arthroplasty: a worldwide retrospective review at 15 to 20 yars. J Arthroplasty 2002;17:675-680

18. Wroblewski BM, Charnley J. Radiographic morphology of the osteoarthritis hip. J Bone Joint Surg Br1982;64:568-569.

19. Tapaninen TS, Venesmaa PK, Jurvelin JS, Miettinen HJ, Kröger HP. Alendronate reduces periprosthetic bone loss after uncemented primary total hip arthroplasty-a 5-year follow-up of 16 patients. Scand J Surg 2010; 99(1):32-37.

20. Arabmotlagh M, Rittmeister M, Hennigs T. Alendronate prevents femoral periprosthetic bone losss following total hip arthroplasty: prospective randomized double-blind study. J Orthop Res 2004; 24(7):1336-1341.

21. Venesmaa PK, Kröger HP, Miettinen HJ, Jurvelin JS, Suomalainen OT, Alhav EM. Alendronate reduces periprosthetic bone loss after uncemented primary total hip arthroplasty: a prospective randomized study. J Bone Miner Res 2001; 16(11):2126-21.

22. Petri K.Venesmaa, Heikki P.J.Kroger, Hannu J. A.Miettinen et al. Alendronate reduces periprosthetic Bone Loss after uncemented primary Hip arthroplasty. Journal of bone and mineral research 2001;16(11)2126-2131

23. Nehme A, Maalouf G, Tricoire JL, Giordano G, Chiron P, Puget J. Ef- fect of alendronate on periprosthetic bone loss after uncemented primary total hip arthroplasty :a prospective randomized study. Rev Chir Orthoped Reparatrice Appar Mot.2003.

24. Nishioka T, Yagi S, Mitsuhashi T, et al. Alendronate inhibits periprosthetic bone loss around uncemented femoral components. J Bone Miner Metab 2007; 25(3):179-183.

25. Wilkinson JM, Stockley I, Peel NF, et al. Effect of pamidronate in preventing local bone loss after total hip arthroplasty: a randomized, double-blind, controlled trial. J Bone Miner Res 2001; 16(3):556-564.

26. Bobyn JD, Mortimer ES, Glassman AH, Engh CA, Miller JE, Brooks CE. Producing and avoiding stress shielding. Laboratory and clinical observations of noncemented total hip. Clin Orthop Relat Res 1992; (274):79-96.

27. Nakamura K. Measurement of periprosthetic bone mineral density after cementless hip arthroplasty by dual energy X-ray absorptiometry:Longitudinal and cross-sectional evaluation. J Orthop Sci 1996; 1:113-122.

28. Venesmaa PK, Kroger HPJ, Miettinen HJA, Jurvelin JS, Suomalainen OT, Alhava EM. Monitoring of periprosthetic BMD after uncemented total hip arthroplasty with dual-energy X-ray absorptiometry a 3 -year follow-up study.J Bone Miner Res200;1 16:1056-1061.

29. Engh CA, McGovern TF, Bobyn JD, Harris WH. A quantitative evaluation of periprosthetic bone -remodeling after cementless total hip arthroplasty. J Bone Joint Surg Am 1992;74:1009-1020. 